\title{
INFLUENCE OF PHOSPHATE IONS ON THE EXTRACTION OF ALUMINUM BY 8-HYDROXYQUINOLINE FROM OH-AL SUSPENSIONS
}

\author{
G. DI PASCALE and A. VIOLANTE \\ Institute of Agricultural Chemistry, University of Naples, 80055 Portici, Naples, \\ Italy. Received 27 May 1985, accepted I2 Feb. 1986. \\ Di Pascale, G. ANd Violante, A. 1986. Influence of phosphate ions on the \\ extraction of aluminum by 8 -hydroxyquinoline from $\mathrm{OH}-\mathrm{Al}$ suspensions. Can. \\ J. Soil Sci. 66: 573-579. \\ Aluminum was extracted from $\mathrm{OH}-\mathrm{Al}$-suspensions $\left(\left[\mathrm{Al}^{3+}\right]=6.4 \times 10^{-4} \mathrm{~mol} \mathrm{~L}^{-1}\right.$; \\ $\mathrm{OH} / \mathrm{Al}$ molar ratio $=1.0,1.5,2.2)$ aged 5 and $18 \mathrm{mo}$ by 8 -hydroxyquinoline into \\ four different species: readily extractable $\left(\mathrm{Al}_{\mathrm{re}}\right)$, moderately extractable $\left(\mathrm{Al}_{\mathrm{me}}\right)$, \\ slowly extractable $\left(\mathrm{AL}_{\mathrm{se}}\right)$ and nonextractable $\left(\mathrm{Al}_{\mathrm{ne}}\right)$ aluminum. In all the systems, \\ the percentages of $\mathrm{Al}_{\mathrm{re}}$ were the highest of the ultrafiltered hydrolytic products of \\ $\mathrm{Al}$, ranging from 68.1 to $21.1 \%$, whereas the percentages of $\mathrm{Al}_{\mathrm{me}}$ and $\mathrm{Al}_{\mathrm{se}}$ were \\ $\leqslant 12.3 \%$. The higher the $\mathrm{OH} / \mathrm{Al}$ molar ratio and the longer the aging period of $\mathrm{OH}-$ \\ $\mathrm{Al}$-suspensions, the lower the percentages of $\mathrm{Al}_{\mathrm{re}}, \mathrm{Al}_{\mathrm{me}}$ and $\mathrm{Al}_{\mathrm{se}}$, and the higher the \\ percentages of $\mathrm{Al}_{\mathrm{ne}}$ (ranging from 13.3 to $71.1 \%$ ). With addition of phosphate ions, \\ increasing the $\mathrm{P} / \mathrm{Al}$ molar ratio from 0.05 to 0.5 decreased $\mathrm{Al}_{\mathrm{re}}$ and increased $\mathrm{Al}_{\mathrm{ne}}$. \\ Finally, it was ascertained that the ultrafiltered aluminum was not completely ex- \\ tracted by 8 -hydroxyquinoline after $3 \mathrm{~h}$. More aluminum was extracted from 3 to \\ $48 \mathrm{~h}$ from the suspensions containing phosphate ions than from those without \\ phosphate.
}

Key words: Aluminum hydrolytic products, phosphate, aluminum extraction, 8hydroxyquinoline

[Effets des ions phosphate sur l'extraction de l'aluminium de suspensions $\mathrm{OH}-\mathrm{Al}$ à l'aide d'hydroxy-8 quinoline.]

Titre abrégé: Effets des ions phosphate sur l'extraction de l'aliminium.

Nous avons procédé à l'extraction de l'aluminium de suspensions $\mathrm{OH}-\mathrm{Al}\left(\left[\mathrm{Al}^{3+}\right]\right.$ $=6,4 \times 10^{-4} \mathrm{~mol} \mathrm{1}^{-1}$; rapport molaire $\left.\mathrm{OH} / \mathrm{Al}=1,0,1,5,2,2\right)$ àgées de 5 ou de 18 mois à l'aide d'hydroxy-8 quinoline et obtenu 4 espèces différentes : facilement extractible $\left(\mathrm{Al}_{\mathrm{re.}}\right)$, modérément extractible $\left(\mathrm{Al}_{\text {m.e. }}\right)$, difficilement extractible $\left(\mathrm{Al}_{\text {s.e. }}\right)$ et non extractible $\left(\mathrm{Al}_{\text {n.e. }}\right)$. Dans tous les systèmes, les pourcentages de $\mathrm{Al}_{\text {r.e. }}$ étaient les plus élevés des produits de l'hydrolyse de l'aluminium après ultra-filtration, variant de 68,1 à $21,1 \%$. Les pourcentages de $\mathrm{Al}_{\text {m.e. }}$ et de $\mathrm{Al}_{\text {s.e. }}$ étaient égaux ou inférieurs à $12,3 \%$. Un rapport molaire $\mathrm{OH} / \mathrm{Al}$ plus élevé et une période de vieillissement des suspensions $\mathrm{OH} / \mathrm{Al}$ plus longue entraînent une baisse des pourcentages de $\mathrm{Al}_{\text {r.e. }}$, de $\mathrm{Al}_{\text {m.e. }}$ et de $\mathrm{Al}_{\text {s.e. }}$ et une augmentation des pourcentages de $\mathrm{Al}_{\text {n.e. }}$. (variant de 13,3 à $71,1 \%$ ). L'ajout d'ions phosphate provoque une augmentation du rapport molaire $\mathrm{P} / \mathrm{Al}$ de 0,05 à 0,5 , diminuant le taux de $\mathrm{Al}_{\text {r.e. }}$ et augmentant le taux de $\mathrm{Al}_{\text {n.e. }}$. On a finalement constaté que l'aluminium ultra-filtré n'était pas complètement extrait par l'hydroxy-8 quinoline après trois heures. Nous avons extrait plus d'aluminium, de 3 à $48 \mathrm{~h}$, à partir des suspensions contenant des ions phosphate qu'à partir des suspensions sans phosphate.

Mots clés: Produits de l'hydrolyse de l'aluminium, phosphate, extraction de l'aluminium, hydroxy-8 quinoline

Can. J. Soil Sci. 66: 573-579 (Nov. 1986) 
It is known that aluminum ions hydrolyze forming various monomeric, polymeric and solid species. Many researchers (Matijevic and Tezak 1953; Brosset et al. 1954; Hsu and Bates 1964; Aveston 1965; Turner 1968), using different analytical methods, have tried to demonstrate the existence of different soluble hydrolytic products of aluminum, from simple monomers or polynuclear ions (e.g., $\mathrm{Al}^{3+}, \mathrm{AlOH}^{2+}$, $\left.\mathrm{Al}(\mathrm{OH})_{2}^{+}, \mathrm{Al}(\mathrm{OH})_{2}^{4+}, \mathrm{Al}_{3}(\mathrm{OH})_{6}^{5+}\right)$ to large polymers (e.g., $\mathrm{Al}_{6}(\mathrm{OH})_{15}^{3+}, \mathrm{Al}_{8}(\mathrm{OH})_{20}^{4}$, $\left.\mathrm{Al}_{24}(\mathrm{OH})_{60}^{12+}, \mathrm{Al}_{54}(\mathrm{OH})_{144}^{18+}\right)$.

The first attempts to determine the various forms of aluminum in solution were carried out by Okura et al. (1962), Turner (1968, 1969), and Turner and Ross (1970). According to Turner (1969), in aluminum salt solutions partially neutralized with a base, the aluminum extractable after $10 \mathrm{~s}$ by 8 -hydroxyquinoline is considered to be made up only of monomers, whereas the aluminum extracted after $30 \mathrm{~min}$ or $3 \mathrm{~h}$ is made up of polynuclear ions $\mathrm{Al}_{6}(\mathrm{OH})_{15}^{3+}$ or amorphous solid species, respectively. Turner $(1968,1969)$ and Turner and Ross (1970) demonstrated that the initial OH/Al molar ratio, the temperature, the speed of addition of a base, the presence of different anions $\left(\mathrm{Cl}^{-}, \mathrm{ClO}_{4}^{-}, \mathrm{NO}_{3}^{-}\right)$and the aging period of solutions have considerable influence on promoting the formation of one form of the hydrolytic products of $\mathrm{Al}$ instead of another.

Luciuk and Huang (1974) and Kwong and Huang (1977) showed that in the presence of anions with strong affinity for aluminum (silicate or citrate), the different forms of $\mathrm{Al}$ (monomers, polymers and solid species) cannot be determined accurately. Thus, it is more expedient to divide the $\mathrm{Al}$ species on the basis of their reactivity with 8-hydroxyquinoline. Also, it is well known that hydrolytic products of aluminum and iron strongly hold phosphate ions and made them difficultly available for plants (Bolan et al. 1985).

The aim of this work was to study the influence of phosphate ions on the extrac- tion of aluminum by 8-hydroxyquinoline from suspensions formed at different $\mathrm{OH} /$ Al molar ratios aged for various periods of time.

\section{MATERIALS AND METHODS}

Stock solutions $(500 \mathrm{~mL})$ of $2.56 \times 10^{-3} \mathrm{~mol}$ $\mathrm{L}^{-1} \mathrm{AlCl}_{3}$ were neutralized by slowly adding (1 $\mathrm{mL} \mathrm{min}^{-1}$ ) $0.01 \mathrm{~mol} \mathrm{~L}^{-1} \mathrm{NaOH}$ until suspensions with $\mathrm{OH} / \mathrm{Al}$ molar ratios of $1.0,1.5,2.2$ were obtained. During the titration, the solutions were thoroughly stirred and their final volumes brought to $2 \mathrm{~L}$ with deionized water to obtain a total aluminum concentration of $6.4 \times$ $10^{-4} \mathrm{~mol} \mathrm{~L}^{-1}$. All the suspensions were kept in polyethylene bottles and aged up to $18 \mathrm{mo}$.

During the aging process, aliquots of each suspension (50-100 $\mathrm{mL}$ ) were filtered through Millipore MF filters of $0.025-\mu \mathrm{m}$ pore size to remove amorphous and/or crystalline solid phases $(>0.025 \mu \mathrm{m})$. The various forms of aluminum were determined in the filtrate as described below.

\section{Determination of Various Forms of Aluminum by 8-hydroxyquinoline}

Aluminum was determined by extraction with 8 hydroxyquinoline by the method proposed by Okura et al. (1962) and modified by Turner (1969). Aliquots of the filtrates were transferred to 50-mL separatory funnels which contained 5 $\mathrm{mL}$ of $\mathrm{H}_{2} \mathrm{O}$ and $14 \mathrm{~mL}$ of 8-hydroxyquinoline solution ( $2 \mathrm{~g}$ of 8 -hydroxyquinoline previously dissolved in $5 \mathrm{~mL}$ of glacial acetic acid and 200 $\mathrm{mL}$ of $\mathrm{H}_{2} \mathrm{O}$ ). The readily-extractable aluminum $\left(\mathrm{Al}_{\mathrm{re}}\right)$ was determined by adding $10 \mathrm{~mL}$ of chloroform, shaking for $10 \mathrm{~s}$ and rapidly removing the chloroform phase. The moderately $\left(\mathrm{Al}_{\text {me }}\right)$ or slowly $\left(\mathrm{Al}_{\mathrm{sc}}\right)$ extractable aluminum species were determined by shaking the $\mathrm{OH}-\mathrm{Al}$-suspensions for $30 \mathrm{~min}$ or $3 \mathrm{~h}$, respectively, with the solution of 8-hydroxyquinoline. After a suitable time of contact, $10 \mathrm{~mL}$ of chloroform were added. After shaking for $15 \mathrm{~s}$, the chloroform phase was removed. The concentration of aluminum in the chloroform extract was determined spectrophotometrically at $395 \mu \mathrm{m}$. The moderately-extractable aluminum $\left(\mathrm{Al}_{\mathrm{me}}\right)$ was determined by subtracting the concentration of the aluminum determined after $10 \mathrm{~s}$ from the concentration of aluminum determined after $30 \mathrm{~min}$. The slowlyextractable aluminum $\left(\mathrm{Al}_{\mathrm{se}}\right)$ was determined by subtracting the concentration of aluminum ex- 
tracted after $30 \mathrm{~min}$ from the concentration of aluminum extracted after $3 \mathrm{~h}$. The slowly-extractable aluminum was also determined after 6 , 18 and $48 \mathrm{~h}$ of contact with 8-hydroxyquinoline solutions. The nonextractable aluminum $\left(\mathrm{Al}_{\mathrm{ne}}\right)$ was determined from the difference between the initial total aluminum concentration $\left(6 \times 10^{-4}\right.$ mol $\mathrm{L}^{-1}$ ) and that determined after $3,6,18$ or $48 \mathrm{~h}$.

\section{Determination of Aluminum after Addition of Phosphate Ions}

Different quantities of $0.025 \mathrm{~mol} \mathrm{~L}^{-1} \mathrm{KH}_{2} \mathrm{PO}_{4}$ solution were added to aliquots of the OH-Alsuspensions, aged 5 or $18 \mathrm{mo}$ and thoroughly stirred to obtain systems with P/Al molar ratios of $0.05,0.08,0.17$ or 0.5 . Before adding the $\mathrm{KH}_{2} \mathrm{PO}_{4}$ solution, its $\mathrm{pH}$ was adjusted to the same $\mathrm{pH}$ as that of the suspension to which it was added. After $24 \mathrm{~h}$, the suspensions were filtered on Millipore filters $(0.025-\mu \mathrm{m}$ pore size) and the various forms of aluminum were determined as previously reported.

\section{RESULTS AND DISCUSSION}

Table 1 shows the percentages of readily$\left(A l_{\text {re }}\right)$, moderately $\left(\mathrm{Al}_{\mathrm{me}}\right)$ or slowly extractable $\left(\mathrm{Al}_{\mathrm{se}}\right)$ aluminum, and of aluminum nonextractable after $3 \mathrm{~h}\left(\mathrm{Al}_{\text {ne }}\right)$ in the $\mathrm{OH}-\mathrm{Al}$ - suspensions $(\mathrm{OH} / \mathrm{Al}$ molar ratio $=1.0,1.5$ or 2.2), aged 5 or 18 mo before and after addition of phosphate ions (P/Al molar ratio $=0,0.05,0.08,0.17$ or 0.5$). \mathrm{Al}_{\text {re }}$ was the most abundant form of $\mathrm{Al}$ in the filtrates ranging from 72.0 to $91.3 \%$ of the aluminum extracted after $3 \mathrm{~h}\left(\mathrm{Al}_{\mathrm{re}}+\mathrm{Al}_{\mathrm{me}}+\mathrm{Al}_{\mathrm{se}}\right)$ in all suspensions.

In the absence of phosphate, the amounts of $\mathrm{Al}_{\mathrm{re}}$ ranged from a maximum of $68.1 \%$ in the suspension at $\mathrm{OH} / \mathrm{Al}=1.0$ aged 5 mo to a minimum of $21.1 \%$ in the suspension at $\mathrm{OH} / \mathrm{Al}=2.2$ aged $18 \mathrm{mo}($ Table 1$)$. The percentages of $A l_{m e}$ or $A l_{s e}$ reached a maximum of 12.3 or $6.3 \%$, respectively, in the system at $\mathrm{OH} / \mathrm{Al}=1.0$ aged $5 \mathrm{mo}$. It was found that the higher the initial $\mathrm{OH} / \mathrm{Al}$ molar ratio or the longer the aging period, the lower the amounts of $\mathrm{Al}_{\text {re }}, \mathrm{Al}_{\text {me }}$ or $\mathrm{Al}_{\mathrm{se}}$, and the higher the amounts of $\mathrm{Al}_{\mathrm{ne}}$. After aging the systems from 5 to $18 \mathrm{mo}, \mathrm{Al}_{\text {ne }}$ increased from 13.3 to $39.3 \%$ in the suspension at $\mathrm{OH} / \mathrm{Al}=1.0$, from 22.8 to $52.6 \%$ in the suspension at $\mathrm{OH} / \mathrm{Al}=1.5$, and from 39.2 to $71.1 \%$ in the suspension at $\mathrm{OH} / \mathrm{Al}$ $=2.2$.

The addition of phosphate to the aged

Table 1. Percentage of hydrolytic products of aluminum (initial OH/Al molar ratio $=1.0,1.5$, or 2.2) aged 5 and $18 \mathrm{mo}$ in the absence or presence of phosphate ions ( $\mathrm{P} / \mathrm{Al}$ molar ratio $=0,0.05,0.08,0.17$ or 0.5 )

\begin{tabular}{|c|c|c|c|c|c|c|c|c|c|}
\hline \multirow{2}{*}{$\begin{array}{l}\text { Aluminum } \\
\text { species }\end{array}$} & \multicolumn{4}{|c|}{$\begin{array}{c}\text { Aged } 5 \text { mo } \\
\text { P/Al molar ratio }\end{array}$} & \multicolumn{5}{|c|}{$\begin{array}{c}\text { Aged } 18 \text { mo } \\
\text { P/Al molar ratio }\end{array}$} \\
\hline & 0 & 0.08 & 0.17 & 0.5 & 0 & 0.05 & 0.08 & 0.17 & 0.5 \\
\hline & \multicolumn{9}{|c|}{$O H / A l=I .0\left(p H_{i}=4.49 ; p H_{j}=3.98\right)$} \\
\hline $\mathrm{Al}_{\mathrm{re}}^{\dagger}$ & 68.1 & 66.6 & 64.9 & 49.2 & 51.9 & 46.7 & 46.2 & 41.6 & 35.4 \\
\hline$A I_{m c}$ & 12.3 & 11.9 & 9.0 & 6.3 & 7.3 & 9.2 & 1.4 & 2.3 & 2.0 \\
\hline $\mathrm{Al}_{s e}$ & 6.3 & 4.8 & 8.0 & 4.9 & 1.5 & 3.7 & 3.0 & 3.3 & 4.1 \\
\hline \multirow[t]{2}{*}{$\mathrm{Al}_{\mathrm{nc}}$} & 13.3 & 16.7 & 18.1 & 39.6 & 39.3 & 41.4 & 48.4 & 52.8 & 58.5 \\
\hline & \multicolumn{9}{|c|}{$O H / A I=1.5\left(p H_{,}=4.60 ; p H_{f}=4.09\right)$} \\
\hline $\mathrm{Al}_{\mathrm{re}}$ & 59.7 & 51.9 & 49.8 & 37.8 & 42.0 & 37.7 & 36.7 & 31.2 & 26.4 \\
\hline $\mathrm{Al}_{\mathrm{trc}}$ & 12.3 & 11.7 & 8.0 & 6.6 & 5.0 & 3.3 & 1.2 & 0.9 & 0.8 \\
\hline $\mathrm{Al}_{\mathrm{sc}}$ & 5.2 & 4.4 & 6.9 & 3.7 & 0.4 & 1.7 & 3.6 & 5.6 & 6.1 \\
\hline \multirow[t]{2}{*}{$\mathrm{Al}_{\mathrm{nc}}$} & 22.8 & 32.0 & 35.3 & 51.9 & 52.6 & 57.3 & 58.5 & 62.3 & 66.7 \\
\hline & \multicolumn{9}{|c|}{$O H / A I=2.2\left(p H_{i}=5.00 ; p H_{t}=4.28\right)$} \\
\hline $\mathrm{Al}_{\mathrm{rc}}$ & 45.3 & 34.8 & 27.3 & 25.2 & 21.1 & 18.0 & 16.6 & 14.2 & 14.1 \\
\hline $\mathrm{Al}_{\mathrm{me}}$ & 11.6 & 9.8 & 8.0 & 5.3 & 3.9 & 3.3 & 0.9 & 0.7 & 0.7 \\
\hline $\mathrm{Al}_{\mathrm{se}}$ & 3.9 & 3.3 & 5.2 & 2.7 & 3.9 & 3.7 & 2.8 & 2.7 & 1.5 \\
\hline $\mathrm{Al}_{\mathrm{ni}}$ & 39.2 & 52.1 & 59.5 & 66.8 & 71.1 & 75.0 & 79.7 & 82.4 & 83.7 \\
\hline
\end{tabular}

$\dagger_{\mathrm{Al}}=$ readily-extractable aluminum; $\mathrm{Al}_{\mathrm{me}}=$ moderately-extractable aluminum; $\mathrm{Al}_{\mathrm{se}}=$ slowly-extractable aluminum; $\mathrm{Al}_{\mathrm{ne}}=$ nonextractable aluminum; $\mathrm{pH}_{\mathrm{i}}=$ initial $\mathrm{pH} ; \mathrm{pH}_{\mathrm{f}}=$ final $\mathrm{pH}$ (after 18 mo of aging). 
$\mathrm{OH} / \mathrm{Al}$-suspensions decreased $\mathrm{Al}_{\mathrm{re}}$ and $\mathrm{Al}_{\mathrm{me}}$ and increased $\mathrm{Al}_{\text {ne }}$ (Table 1). $\mathrm{Al}_{\text {se }}$ slightly increased at certain P/Al molar ratios. However, the sum of the percentages of $\mathrm{Al}_{\mathrm{mc}}$ and $\mathrm{Al}_{\mathrm{se}}$ was usually less than that determined in the phosphate-free systems.

Clearly, phosphate ions, because of their strong affinity for Al ions (Hsu 1975, 1977, 1978; Bowden et al. 1980; Bolan et al. 1985; Violante and Huang 1985) promoted the formation of new solid and/or soluble species (as will be discussed later) and influenced the extractability of the $\mathrm{Al}$ ions by 8-hydroxyquinoline. Our data extend the work of Kwong and Huang (1977) showing that the presence of foreign ligands strongly influences the rate of removal of $\mathrm{Al}$ from suspensions. Kwong and Huang (1977) found that the effect of citric acid, co-precipitated with $\mathrm{Al}$, on the formation of the readily-extractable $\mathrm{Al}$ and moderatelyextractable Al by 8-hydroxyquinoline varied with the initial concentrations of $\mathrm{Al}$ and citric acid, and $\mathrm{OH} / \mathrm{Al}$ molar ratios of the $\mathrm{OH}-\mathrm{Al}$-suspensions. From our study it is evident that the addition of phosphate ions increased the proportion of nonextractable aluminum at the expense of the readily, and moderately-extractable aluminum.

Table 2 shows the percentage decrease of $\mathrm{Al}_{\mathrm{re}}$ with respect to $\mathrm{Al}$ re at $\mathrm{P} / \mathrm{Al}$ molar ratio $=0$, after addition of different amounts of phosphate ions. Generally, at a given $\mathrm{P} / \mathrm{Al}$ molar ratio, the higher the initial $\mathrm{OH} / \mathrm{Al}$ molar ratio or the longer the aging period of the $\mathrm{OH}-\mathrm{Al}$-suspensions, the greater was the percentage decrease of $\mathrm{Al}_{\mathrm{re}}$. For example after addition of $0.17 \mathrm{~mol}$ of phosphate per mol of aluminum, the percentage decreases of $\mathrm{Al}_{\mathrm{re}}$ were $4.7,16.6$ and $39.7 \%$, respectively, in the systems at $\mathrm{OH} / \mathrm{Al}=$ $1.0,1.5$ and 2.2 aged 5 mo. In the same suspensions aged $18 \mathrm{mo}$, the percentage decreases of $\mathrm{Al}_{\mathrm{re}}$, after addition of $0.17 \mathrm{~mol}$ of phosphate were $19.8,25.7$ and $32.7 \%$, respectively.

These findings cannot be interpreted without ambiguity, because the nature of hydrolytic products of aluminum and the reaction products between phosphate and $\mathrm{Al}$ ions are not known precisely. However, a possible explanation is that in the $\mathrm{OH}-\mathrm{Al}$ suspensions with higher $\mathrm{OH} / \mathrm{Al}$ molar ratios (i.e., $\mathrm{OH} / \mathrm{Al}=2.2$ ) or aged for a longer

Table 2. Percentage decrease of $\mathrm{Al}_{\mathrm{re}}$ in $\mathrm{OH}$-Al-suspensions aged 5 and 18 mo after addition of different amounts of phosphate ions (from the data reported in Table 1)

\begin{tabular}{|c|c|c|c|c|}
\hline \multirow{2}{*}{$\begin{array}{l}\text { P/Al molar } \\
\text { ratios }\end{array}$} & \multicolumn{2}{|c|}{ Aged $5 \mathrm{mo}$} & \multicolumn{2}{|c|}{ Aged $18 \mathrm{mo}$} \\
\hline & $\%$ decrease $\mathrm{Al}_{\mathrm{re}}$ & $\mathrm{R} \dagger$ & $\%$ decrease $\mathrm{Al}_{\mathrm{re}}$ & $\mathrm{R} \dagger$ \\
\hline \multicolumn{5}{|c|}{$O H / A l=1.0$} \\
\hline 0.05 & - & - & 10.0 & 2.0 \\
\hline 0.08 & 2.2 & 0.3 & 11.0 & 1.4 \\
\hline 0.17 & 4.7 & 0.3 & 19.8 & 1.2 \\
\hline 0.5 & 27.7 & 0.5 & 31.8 & 0.6 \\
\hline \multicolumn{5}{|c|}{$O H / A l=1.5$} \\
\hline 0.05 & - & - & 10.2 & 2.0 \\
\hline 0.08 & 13.1 & 1.6 & 12.6 & 1.6 \\
\hline 0.17 & 16.6 & 1.0 & 25.7 & 1.5 \\
\hline 0.5 & 36.7 & 0.7 & 37.1 & 0.7 \\
\hline \multicolumn{5}{|c|}{$O H / A l=2.2$} \\
\hline 0.05 & - & - & 14.7 & 2.9 \\
\hline 0.08 & 22.5 & 2.8 & 21.3 & 2.7 \\
\hline 0.17 & 39.7 & 2.3 & 32.7 & 1.9 \\
\hline 0.5 & 44.4 & 0.9 & 33.2 & 0.7 \\
\hline
\end{tabular}

$+\mathrm{R}$ indicates the ratio between the percentage decrease of $\mathrm{Al}_{\mathrm{re}}$ and the $\mathrm{P} / \mathrm{Al}$ molar ratio expressed as percentage $(5,8,17$ or $50 \% \mathrm{P})$. 
period of time (i.e., $18 \mathrm{mo}$ ), the hydrolytic soluble products of $\mathrm{Al}$ are much more neutralized and have a lower positive charge per $\mathrm{Al}$ atom (Hsu and Bates 1964; Smith and Hem 1972; Bersillon et al. 1980). The reaction of such species with phosphate ions would further decrease their positive charge, with a consequent lower electrostatic repulsion of the species formed, which could then more easily coalesce and precipitate (Hsu and Bates 1964; Hsu 1977, 1978).

Table 2 also shows the ratios $(R)$ between the percentage decrease of $\mathrm{Al}_{\mathrm{re}}$ and the $\mathrm{P} /$ $\mathrm{Al}$ molar ratio expressed as a percentage (5, 8,17 or $50 \%$ ). These ratios may be used as an indicator of the capacity of phosphate ions to decrease the aluminum readily extractable by 8 -hydroxyquinoline. These results show that increasing the P/Al molar ratios increased the percentage decrease of $\mathrm{Al}_{\mathrm{re}}$ in all the suspensions aged 5 or $18 \mathrm{mo}$, but usually decreased the $R$ values (Table 2). For example, in the suspension at $\mathrm{OH} /$ $\mathrm{Al}=1.0$ aged $18 \mathrm{mo}$, by increasing the $\mathrm{P} /$ Al ratio from 0.05 to 0.5 , the percentage decrease of $\mathrm{Al}_{\mathrm{re}}$ increased from 10 to 31.8 whereas the $R$ values decreased from 2.0 to 0.6 . These data suggest that at the lower $\mathrm{P} /$ $\mathrm{Al}$ molar ratios (Al present in larger excess than phosphate), the more Al was removed for each phosphate ion added. Our results seem to confirm the findings of Hsu (1975) that phosphate reacts completely with $\mathrm{Al}$ only in the presence of a large excess of $\mathrm{Al}$ ions and that the higher the P/Al molar ratio, the higher the amount of phosphate re- maining in solution. Indeed the fixation of phosphate ions makes the surface of the hydrolytic products of aluminum more negative at all $\mathrm{pH}$ values (Bowden et al. 1980), probably preventing the further adsorption of other phosphate ions, mainly at higher P/ Al molar ratios.

\section{Kinetics of Aluminum Extraction}

Table 3 shows the percentages of aluminum extracted by 8 -hydroxyquinoline after 3,6 , 18 and $48 \mathrm{~h}$ from the $\mathrm{OH}-\mathrm{Al}$-suspension at $\mathrm{OH} / \mathrm{Al}=1.5$ aged 18 mo after addition of increasing amounts of phosphate ( $\mathrm{P} / \mathrm{Al}$ from 0 to 0.5$)$. According to Turner $(1968,1969)$ and Turner and Ross (1970), $3 \mathrm{~h}$ of contact should be sufficient to extract all the soluble species of aluminum as well as an initial solid phase present in partially neutralized Al salt solutions.

Our results show that in the absence or presence of phosphate, aluminum was not completely extracted after $3 \mathrm{~h}$. In the absence of phosphate, aluminum continued to be extracted even after $48 \mathrm{~h}$, although the amount extracted between 3 and $48 \mathrm{~h}$ did not exceed $15 \%$ of the total amount extracted after $48 \mathrm{~h}$ (Table 3). Evidently, in the absence of phosphate, filterable solid species $(<0.025 \mu \mathrm{m})$ of different crystallinity or large and/or well-structured polymers (Hsu and Bates 1964; Turner 1976; Bersillon et al. 1980) could be the species from which Al was extracted after more than $3 \mathrm{~h}$. The Al extracted between 3 and $48 \mathrm{~h}$ with respect to the total Al extracted after $48 \mathrm{~h}$ was higher from the suspensions

Table 3. Effect of extraction time on the percentage of aluminum extractable by 8-hydroxyquinoline from ultrafiltered $\mathrm{OH}-\mathrm{Al}$-suspensions $(\mathrm{OH} / \mathrm{Al}=1.5)$ aged $18 \mathrm{mo}$ with differing $\mathrm{P} / \mathrm{Al}$ molar ratios

\begin{tabular}{lccccc}
\hline \hline & \multicolumn{5}{c}{ P/Al molar ratio } \\
\cline { 2 - 5 } Time of extraction (h) & 0 & 0.05 & 0.08 & 0.17 & 0.5 \\
\hline 3 & 47.5 & 42.7 & 41.6 & 37.8 & 33.3 \\
6 & 51.1 & 46.8 & 43.9 & 45.5 & 37.8 \\
18 & 53.6 & 49.0 & 49.4 & 47.2 & 39.6 \\
48 & 55.3 & 54.1 & 51.9 & 52.6 & 50.3 \\
Percent of Al extracted & & & & \\
between 3 and 48 h to Al & & 21.1 & 20.0 & 28.1 & 33.8 \\
extracted after 48 h & 14.1 & & & & \\
\hline
\end{tabular}


containing phosphate ions than from those without phosphate. Furthermore, increasing the P/Al molar ratio increased the amount of $\mathrm{Al}$ extracted after $3 \mathrm{~h}$.

It is interesting to note that after $3 \mathrm{~h}$ of extraction by 8 -hydroxyquinoline, $47.5 \%$ of aluminum was removed from the suspension at $\mathrm{P} / \mathrm{Al}=0$, whereas only $33.3 \%$ was extracted from the suspension at P/Al $=0.5$. In contrast, after $48 \mathrm{~h}$ of extraction, the amounts of aluminum removed in the presence of different $\mathrm{P} / \mathrm{Al}$ ratios were similar ranging from $55.3 \%(\mathrm{P} / \mathrm{Al}=0)$ to $50.3 \%(\mathrm{P} / \mathrm{Al}=0.5$; Table 3$)$.

Evidently, the addition of phosphate ions caused the formation of amorphous solid species (Hsu 1978; Violante and Huang $1985)$ of extremely small size $(<0.025 \mu \mathrm{m})$ as well as soluble species with a lower charge, as shown, for example, in Fig. 1.

The Al ions from the solid or soluble species are slowly extractable by 8 -hydroxyquinoline because of the strong binding of $\mathrm{Al}$ with phosphate ions. Such species would prevail in the systems with higher $\mathrm{P} /$ $\mathrm{Al}$ molar ratios and require longer than $3 \mathrm{~h}$ to be extracted.

Kwong and Huang (1977) found that citrate ions decreased the amount of $\mathrm{Al}$ precipitated $(>0.025 \mu \mathrm{m})$ whereas we found that phosphate ions strongly increased the amount of $\mathrm{Al}_{\text {re }}$ (Tables 1 and 3) which included precipitated hydrolytic products retained by filtration. Although the exact amount of Al precipitated $(>0.025 \mu \mathrm{m})$ was not determined in this study, it seems logical to conclude that the large increases of $\mathrm{Al}_{\text {ne }}$ (Table 1) after addition of phosphate ions were due to the formation of soluble species and/or very fine colloidal particles $(<0.025 \mu \mathrm{m})$, both very slowly extractable by 8 -hydroxyquinoline (Table 3 ), rather than to the formation of precipitates ( $>$
$0.025 \mu \mathrm{m}$ ) which were retained by ultrafiltration.

In conclusion, the interaction between phosphate ions and the hydrolytic products of aluminum leads to the formation of new solid and/or soluble species and retards the rate of removal of aluminum ions from solution by 8 -hydroxyquinoline. The decrease of readily, moderately or slowly extractable aluminum seems to be influenced not only by the amount of phosphate ions added (P/Al molar ratio), but also by the initial $\mathrm{OH} / \mathrm{Al}$ molar ratio and aging period of the OH-Al-suspensions. Generally at a given $\mathrm{P} / \mathrm{Al}$ molar ratio, the higher the initial $\mathrm{OH} / \mathrm{Al}$ molar ratio or the longer the aging period of the $\mathrm{OH}-\mathrm{Al}$-suspensions, the lower the amount of Al extracted after $3 \mathrm{~h}$. Lastly, more aluminum was extracted by 8-hydroxyquinoline from 3 to $48 \mathrm{~h}$ from the suspensions containing phosphate ions than from those without phosphate.

Aveston, J. 1965. Hydrolysis of the aluminum ion: ultracentrifugation and acidity measurements. J. Chem. Soc. 4438-4443.

Bersillon, J. L., Hsu, P. H. and Fiessinger, F. 1980. Characterization of hydroxy aluminum solutions. Soil Sci. Soc. Am. J. 44: 630-634.

Bolan, N. S., Barrow, N. J. and Posner, A. M. 1985. Describing the effect of time on sorption of phosphate by iron and aluminium hydroxides. J. Soil Sci. 36: 187-197.

Bowden, J. W., Nagarajah, S., Barrow, N. J., Posner, A. M. and Quirk, J. P. 1980. Describing the adsorption of phosphate, citrate and selenite on a variable-charge mineral surface. Aust. J. Soil Res. 18: 49-60.

Brosset, C., Biederman, G. and Sillen, L. G. 1954. Studies on the hydrolysis of metal ions. $\mathrm{XI}$. The aluminum ion $\mathrm{Al}^{\mathrm{3}+}$. Acta Chem. Scand. 8: $1917-1926$

Hsu, P. H. 1975. Precipitation of phosphate from solution using aluminum salts. Water Res. 9: 1155-1161

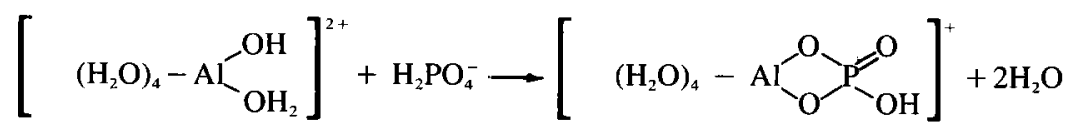

Fig. 1. A possible formation of an Al soluble species by the addition of phosphate. 
Hsu, P. H. 1977. Aluminum hydroxides and oxyhydroxides. Pages 99-143 in J. B. Dixon and S. B. Weed, eds. Minerals in soil environments. Soil Sci. Soc. Am., Madison, Wis.

Hsu, P. H. 1978. Effect of phosphate and silicate on the crystallization of gibbsite from $\mathrm{OH} /$ Al solutions. Soil Sci. 127: 219-226.

Hsu, P. H. and Bates, T. F. 1964. Formation of X-ray amorphous and crystalline aluminum hydroxides. Mineral. Mag. 33: 749-768.

Kwong, Ng Kee, K. F. and Huang, P. M. 1977. Influence of citric acid on the hydrolytic reactions of aluminum. Soil Sci. Soc. Am. J. 41: 692-697.

Luciuk, G. M. and Huang, P. M. 1974. Effect of monosilicic acid on hydrolytic reactions of aluminum. Soil Sci. Soc. Am. Proc. 38: 235244.

Matijevic, E. and Tezak, B. 1953. Detection of polynuclear complex aluminum ions by means of coagulation measurement. J. Phys. Chem. 57: 951-954.

Okura, T., Goto, K. and Yotuyanagi, T. 1962. Forms of aluminum determined by an 8quinolinolate extraction method. Am. Chem. 34: 581-582.

Smith, R. W. and Hem, J. D. 1972. Effect of aging on aluminum hydroxide complexes in dilute aqueous solutions. U.S. Geol. Surv. Water Supply Paper 1827. 51 p.

Turner, R. C. 1968. Conditions in solution during the formation of gibbsite in dilute $\mathrm{Al}$ salt solutions. I. Theoretical treatment of the effect of the formation of mono- and polynuclear hydroxy aluminum ions, precipitations and crystallization on curves representing the titration of $\mathrm{AlCl}_{3}$ with a base. Soil Sci. 106: 291-296.

Turner, R. C. 1969. Three forms of aluminum in aqueous system determined by 8-quinolinolate extraction method. Can. J. Chem. 47: 25212527.

Turner, R. C. 1976. Effect of aging on properties of polynuclear hydroxy aluminum cations. Can. J. Chem. 54: 1528-1534.

Turner, R. C. and Ross, G. J. 1970. Conditions in solution during the formation of gibbsite in dilute $\mathrm{Al}$ salt solutions. 3. Effect of $\mathrm{Cl}$ concentration and temperature and a proposed mechanism for gibbsite formation. Can. J. Chem. 48: 723-729.

Violante, A. and Huang, P. M. 1985. Influence of inorganic and organic ligands on the formation of aluminum hydroxides and oxyhydroxides. Clays Clay Miner. 33: 181-192. 